\title{
SAMUEL RUTHERFORD - MONARCHIA PRAWA CZY MONARCHIA ŚWIĘTYCH?
}

\begin{abstract}
Streszczenie. Samuel Rutherford - szkocki prezbiteriański pastor i myśliciel polityczny okresu angielskiej wojny domowej - uważany jest powszechnie za jednego z teoretyków koncepcji monarchii prawa, ustroju mieszanego oraz prawa oporu. Wszystkie te idee, konstytuujące nowożytny angielski konstytucjonalizm w opozycji do monarszego absolutyzmu, wywodzi z koncepcji umowy społecznej, co czyni zeń autora, do którego odwoływali się dla przykładu Ojcowie Założyciele w swym sprzeciwie wobec arbitralnej władzy metropolii. Tymczasem analiza całości jego dorobku każe poddać w wątpliwość wiele obiegowych opinii na temat autora Lex, Rex. W niniejszym artykule autor dowodzi, że hermeneutyczna analiza teologii politycznej Rutherforda skłania do wniosku, że nie był on teoretykiem monarchii prawa w jej powszechnym znaczeniu, lecz w istocie teonomicznej wizji państwa.
\end{abstract}

Slowa kluczowe: Rutherford; monarchia prawa; angielska wojna domowa.

Król, jako Król, powinien mieć z sobą księgę prawa zasiadając na tronie, by byta jego przewodnikiem. ${ }^{1}$

Samuel Rutherford, A free disputation against pretended liberty of conscience

\section{WPROWADZENIE}

Monarchia prawa jest bez wątpienia jednym $\mathrm{z}$ fundamentalnych zagadnień związanych z klasyczną angielską refleksją polityczno-prawną. Za sprawą choćby Henry'ego Bractona, Johna Fortescue'a, czy Thomasa Smitha rozważania nad zakresem monarszej prerogatywy oraz uprawnieniami poddanych stały się jądrem argumentacji na rzecz takiej czy innej wizji ustroju politycznego. Były też asumptem do analizy istoty i genezy prawa królestwa oraz jego relacji z osobą monarchy. Niewiele w tym względzie zmieniło odłączenie się przez Henryka VIII od wspólnoty katolickiej, a nowa reformowana anglikańska teologia, choćby za sprawą Richarda Hookera, dalej tkwiła w siatce pojęciowej wyznaczonej przez wcześniejszych fundatorów tego stylu myślenia o polityce i prawie. Stylu, który przemożny wpływ kładł

* Uniwersytet Łódzki, Wydział Prawa i Administracji, Katedra Doktryn Polityczno-Prawnych, ttulejski@tlen.pl.

${ }^{1}$ Tłumaczenia fragmentów dzieł pochodzą od autora artykułu. 
na tradycję polityczną wspólnoty i jej zaszłość, w tle mając jedynie teologiczny kontekst, w którym funkcjonowała, był on bowiem przedmiotem niekwestionowanego konsensusu i naturalnym normatywnym środowiskiem, w jakim prowadzone były rozważania nad monarchią prawa. Choć bowiem Akt Supremacji uczynił z króla Anglii zwierzchnika kościoła, to zachował on w istocie katolicką doktrynę polityczną i społeczną, dostosowując je jedynie do nowych okoliczności i używając pojęć wypracowanych jeszcze w średniowieczu. Nie wszyscy jednak pojęcia te interpretowali w tym samym duchu, nadając im mimowolnie lub z premedytacją całkowicie nowy sens, tworząc koncepcje polityczne, które tylko z nazwy odwoływały się do starej i szacownej angielskiej tradycji. Klinicznym niejako przykładem może być tutaj postać Samuela Rutherforda, prominentnego szkockiego prezbiteriańskiego teologa, którego filozofia, a właściwie teologia polityczna, znalazła się w centrum angielskiej debaty za sprawą konfliktu Karola I z Parlamentem. Już wcześniej widoczna była szkocka infiltracja angielskiej debaty teologicznej i politycznej (choćby przez myśl Johna Knoxa i George'a Buchanana), lecz za sprawą Uroczystej Ligi i Przymierza oraz Westminsterskiego Zgromadzenia Świętych refleksja polityczna północnego sąsiada zdominowała dyskurs, jaki toczył się w okresie przed i w trakcie Wielkiej Rebelii. Zapewne z tego powodu najważniejsze dzieło polityczne Rutherforda - Lex, Rex (opublikowane w trakcie negocjacji pomiędzy królem i parlamentem w Oxford i Ubridge, Campbell 1941, 211) - do dnia dzisiejszego uchodzi za jeden z kamieni węgielnych koncepcji monarchii prawa, ustroju mieszanego oraz prawa oporu. Wszystkie te idee, konstytuujące nowożytny angielski konstytucjonalizm w opozycji do monarszego absolutyzmu, wywodzi z koncepcji umowy społecznej, co czyni zeń autora, do którego odwoływali się dla przykładu Ojcowie Założyciele w swym sprzeciwie wobec arbitralnej władzy metropolii. Diagnoza ta jest jednak spowodowana faktem, że na myśl Rutherforda patrzy się jedynie lub przede wszystkim przez pryzmat jego najważniejszego dzieła. Tymczasem analiza całości jego refleksji odnoszącej się do przedmiotu niniejszej analizy każe poddać w wątpliwość wiele obiegowych opinii na temat autora Lex, Rex. Stąd moim celem będzie wykazanie, że hermeneutyczna analiza teologii politycznej Rutherforda skłania do wniosku, że nie był on teoretykiem monarchii prawa, lecz w istocie teonomicznej wizji państwa. Na początku zarysuję koncepcję kontraktowej genezy społeczeństwa i państwa w teologii politycznej Rutherforda. Przejdę następnie do jego koncepcji ustroju i rządów prawa. W ostatniej części zestawię ją z koncepcją starożytnej konstytucji, by wykazać, że jest ona nie do pogodzenia $\mathrm{z}$ głoszonym przez Rutherforda absolutnym prymatem prawa Bożego.

\section{GENEZA SPOLECZEŃSTWA I PAŃSTWA}

Dla Rutherforda społeczeństwa ludzkie są realizacją zaszczepionej przez Boga skłonności do jednoczenia się, będącego wyrazem społecznej natury człowieka. Skłonność tę odnajduje naturalny rozum, który Rutherford nazywa 
„osądem Boga” (Rutherford 1843, 5). Jest on częścią prawa natury wiodącego ludzi ku społeczeństwu politycznemu. Lecz choć idea ta jest częścią porządku natury, to jej realizacja następuje w porządku konwencji, co w sposób istotny odróżnia społeczeństwo od rodziny, do której przynależność nie jest kwestią wyboru. Zatem, mimo że idea społeczeństwa stała się częścią ludzkiej natury przez sam akt Stworzenia, to samo powstanie konkretnego społeczeństwa ma charakter dobrowolny i wolicjonalny.

Ponieważ - twierdzi więc Rutherford - społeczeństwo domowe jest naturalnym przykładem, tak społeczeństwo obywatelskie jest naturalne in radice w swych korzeniach, lecz dobrowolne in modo, w sposób koalescencyjny. Zakładając więc - kontynuuje - że ludzie łączą się w społeczeństwo, lub że społeczeństwo nie zawiera się w rodzinie, wtedy naturalne jest, że ludzie przyłączają się do społeczeństwa obywatelskiego, choć sposób zjednoczenia w ciele politycznym, jak mówi Bodin, jest dobrowolny (Rutherford 1843, 1-2).

W odróżnienia więc od tradycji średniowiecznej i wczesnonowożytnej, u Rutherforda społeczeństwo przyjmuje, przynajmniej na poziomie koncepcyjnym, formę dobrowolnej organizacji wolnych i równych jednostek jednoczących się dla wspólnego celu istniejącego już wcześniej w ich świadomości. Jeśliby szukać genezy tak radykalnego odwrotu od tradycji arystotelejskiej, sięgnąć należy, co istotne dla dalszej części wywodu, do charakterystycznej dla radykalnych koncepcji kalwińskich idei przymierza (covenant). Nie wdając się przy tym w szczegółowe rozważania, koncepcja ta doszukiwała się archetypu wszelkich ludzkich agregacji i porozumień w biblijnym Przymierzu zawartym pomiędzy Adamem i później Abrahamem a Bogiem, które stało się w kalwińskiej teologii rodzajem specjalnej konstytucji danej przez Stwórcę rodzajowi ludzkiemu. Zwłaszcza w Szkocji idea ta trafiła na podatny grunt, gdzie od dawna istniała tradycja kontraktów pomiędzy klanami i ich grupami. Związki, pakty i przysięgi zawierane były tu dla celów wspólnej obrony i polubownego załatwiania sporów. W konsekwencji powstał tam pomysł, by konstrukcję tę wykorzystać dla uzasadnienia prawowitości i celów relacji publicznych (Elazar 1996, 271), co nadaje całej szkockiej myśli prezbiteriańskiej zdecydowanie bardziej indywidualistyczny charakter. Doszło do tego dzięki przetłumaczeniu języka biblijnego na język polityki, by zaaplikować starotestamentowe prawdy do porządku społecznego. W narracji tej przymierze jest moralnie uzasadnioną umową bazującą na dobrowolnej zgodzie ustanowionej poprzez przysięgę lub przyrzeczenie pomiędzy ludźmi lub ich agregacjami na zasadzie niezależności i równości stron. Zawarte jest ono pod określonymi warunkami, dla określonych celów i respektowane przez wszystkie strony. Figura przymierza służyła w ten sposób protestantom jako instrument uzasadnienia takiego, a nie innego charakteru relacji społecznych i politycznych. W tej optyce są one prostym przedłużeniem przymierza zawartego pomiędzy Bogiem i ludźmi, przekształcającego ich w chrześcijańską wspólnotę, a do samej ich istoty należy zgoda i obietnica (Elazar 1995, 22-23). Stąd samo społeczeństwo, 
choć realizujące przyrodzone człowiekowi skłonności, powstaje wedle Rutherforda w taki właśnie dobrowolny i konwencjonalny sposób. Idąc dalej, wszystkie relacje społeczne, tak prywatno- jak i publicznoprawne, zostały oparte na zgodzie i wzajemnej odpowiedzialności (Miller 1956, 48-49), stąd wniosek, że organizacja kościelna i relacje pomiędzy władzą a poddanymi oparte powinny być na tych samych zasadach (Gough 1975, 84).

U Rutherforda ów kontraktualny woluntaryzm obejmuje nie tylko powstanie samego społeczeństwa, lecz także władzy politycznej. Podobnie jak rzecz ma się ze społeczeństwem, także sama idea władzy jest elementem porządku naturalnego danego przez Boga i zaszczepionego w naturze człowieka.

Cała władza polityczna - pisze więc - wywodzi się bezpośrednio z Boskich korzeni, ponieważ: 1. Bóg uczynił człowieka istotą społeczną i ten, kto pragnie być rządzony przez człowieka, z pewnością musiał umieścić tę moc w ludzkiej naturze z dobrego powodu, jak naucza Arystoteles. 2. Bóg i natura mają na celu politykę i pokój ludzkości, stąd Bóg i natura dały ludzkości moc, by zmierzyła się z tym celem i musi nią być władza rządu (Rutherford 1843, 1).

Z samej więc społecznej natury człowieka wynika potrzeba istnienia władzy mogącej zapewnić wspólnocie przetrwanie i pokój. Jak w całej niemal tradycji reformowanej, dla Rutherforda państwo jest więc ustanowionym przez Boga porządkiem narzuconym na upadłego człowieka jako remedium na jego grzech.

Jeśli - pisze Rutherford - wszyscy byliby bezgrzeszni, nie czyniliby innym gwałtu, prawo mogłoby rządzić wszystkimi i wszyscy ludzie mogliby je egzekwować, agendo sponte, przez czynienie dobra z własnej woli, to nie potrzebowaliby króla, który zmuszałby ich do tego. Ale ponieważ ludzie z natury sprzeciwiają się dobrym prawom, dlatego istnieje potrzeba władcy (Rutherford 1843, 101).

By społeczeństwo mogło trwać, musi więc istnieć siła, która zdolna będzie poskromić indywidualne rządze grzesznych ludzi i zjednoczyć ich wysiłki w jednym kierunku. Dlatego Bóg, najwyższy Pan i Król całego świata, namaszcza urzędników, by będąc Mu podlegli, sprawowali władzę nad ludem dla Jego chwały i dobra wspólnego. „Królewskie imperium - przekonuje więc Rutherford - jest zasadniczo po to, by nakarmić, kierować, obronić oraz rządzić w pokoju i pobożności (1 Tm. II.2), jak czyni to ojciec swych dzieci” (Rutherford 1843, 64). „Chrystus - pisze dalej - używa chrześcijańskich urzędników jako swe sługi, by przegonić wilki od swej trzody" (Rutherford 1649, 192). Bóg wyposażył ich więc w prawo miecza, by karali upadłych oraz nakłaniali do podążania ścieżką prawa, dobra i cnoty. Król jest zatem publicznym sługą, który chroni społeczeństwo i wykonawcą woli Boga dla dobra, bezpieczeństwa, pokoju i zbawienia ludzi. Choć więc człowiek jest z natury grzeszny, to dzięki światłu naturalnego rozumu możliwe jest powołanie do życia porządku politycznego, by skłonić ludzi do porządku i dyscypliny. Dlatego oświecone prawem natury, zjednoczone w społeczeństwie jednostki dojść muszą do konkluzji, że konieczne jest istnienie władzy wyposażonej w prawo miecza. 
Analizując sposób jej powołania, Rutherford nie wątpi, że ma ona konwencjonalny charakter. Na mocy prawa natury ludzie posiadają zdolność wyznaczania sobie władców i podporządkowania się prawu. Gdy więc ludzie gromadzą się, w naturalny i oczywisty sposób pojawia się konieczność istnienia władzy, jako nieodzowna konsekwencja pragnienia samozachowania, zaszczepiona w ludzkiej duszy przez Boga. Ten naturalny, przyrodzony instynkt kieruje ludzi ku władzy powodując, że „przekazujemy naszą władzę w ręce jednego lub większej liczby władców" (Rutherford 1843, 2). Odkąd więc Bóg zaszczepił w ludzkiej duszy pragnienie przetrwania, ustanowił konieczność istnienia tych, którzy będą o nie zabiegać, ograniczając jednak równocześnie analogiczne prawo jednostki. Dlatego:

Indywidualne osoby powołując władzę nie zrzekają się swych uprawnień, lecz zrzekają się swej władzy zadania gwałtu innym członkom wspólnoty. Zatem nie będą mieć moralnego prawa czynienie krzywdy bez kary; i to nie jest uprawnienie czy wolność, lecz służebność, ponieważ władza stosowania przemocy i czynienia krzywdy nie jest wolnością, lecz służebnością i poddaństwem (Rutherford 1843, 25-26).

W ten sposób rządzący są danym przez Boga remedium na przemoc i niesprawiedliwość będące skutkiem grzesznej ludzkiej natury - „żywym, racjonalnym, oddychającym prawem zwanym królem, sędzią, ojcem" (Rutherford 1843, 116). Ta władza wynoszenia królów jest immanentnie przypisana ludowi, którego zgoda każdocześnie legitymizuje króla.

Władza ta - pisze - jest radykalnie naturalna, tak samo jak pszczoły (jak sądzą niektórzy) mają moc wyboru swej królowej, tak wspólnota ma naturalną władzę bronić się i ochraniać; i Bóg objawił w Deut. XVII. 14, 15 sposób wyboru naczelników i królów, który jest specjalnym środkiem obrony i ochrony; a lud jest głównym źródłem i fontanną władzy królewskiej (Rutherford 1843, 203).

\section{USTRÓJ I RZĄDY PRAWA}

O ile sama idea władzy dana jest przez Boga, będąc częścią stworzonego przez Niego porządku naturalnego, to Rutherford nie znajduje w nim żadnych wskazówek, jaki sposób jej realizacji miły jest Stwórcy. Wybór tej czy innej formy rządu należy więc do „pozytywnego i wtórnego prawa narodów” (Rutherford 1843, 2), jest więc wynikiem okoliczności mających źródło w woli człowieka (Sanderson 1989, 19). Bóg nie formułuje jednego jasnego rozkazu co do wyboru formy rządów. Prawo natury mówi tylko, że muszą być ojcowie i matki w rodzinie i rządcy w społeczeństwie politycznym. Nawet monarchia, będąca ustrojem biblijnym i elementem powszechnego doświadczeniem w czasach Rutherforda, nie ma charakteru koniecznego (Rutherford 1843, 52). „Ponieważ - pisze - wolność jest naturalna dla wszystkich, z wyjątkiem wolności od bycia poddanym rodzicom, polityczne podporządkowanie jest jedynie przypadkowe, wynikające z pewnych 
pozytywnych praw ludzkich" (Rutherford 1843, 51). Dlatego kiedy ludzie przekazują władzę nad sobą w ręce jednego lub większej liczby ludzi, wtedy nie dzieje się to już za sprawą ich wolnej decyzji. Bóg wyświęca samą władzę, lecz to ludzie ustanawiają jej konkretną formę i tych, a nie innych rządców. Władza polityczna nie przynależy bowiem naturalnie żadnemu człowiekowi, ponieważ z natury ludzie nie podlegają żadnemu rządowi. Władza urzędnika powstała przez rezygnację jednostek z ich wolności jest więc sztuczna i opiera się na jakiejś formie zgody czy porozumienia (Rutherford 1843, 2). I to właśnie ma dla Rutherforda najważniejsze znaczenie, determinuje bowiem istnienie wzajemnych praw i obowiązków oraz określa charakter uprawnienia i zobowiązania politycznego. Władza rządzących pochodzi wprawdzie od Boga, lecz nie bezpośrednio, a poprzez dokonujących jej wyboru ludzi. Ma też swe źródło w umowie, czyli wzajemnym porozumieniu zawartym na określonych warunkach. Dlatego ,jest to oczywiste zobowiązanie Króla wobec ludu w akcie koronacji i ludu wobec króla, jak w umowach pomiędzy panem i wynajętym sługą, czy między dwoma kupcami” (Rutherford 1649, 218-219). Z samego prawa natury wynika równocześnie, że „Bóg wyznaczył króla lub naczelnika, który troszczył będzie się o tę wspólnotę, będzie rządzić nią w pokoju i ochroni wszystkich przed wzajemnymi aktami przemocy" (Rutherford 1843, 69). Powołanie rządcy nakłada na niego zatem konkretne obowiązki i Rutherford ujmuje to następująco:

Po pierwsze, wyznaczenie przez rzeczpospolitą władców, by rządzili, nie jest czynem obojętnym, lecz moralnym, ponieważ ich nieustanowienie jest, jak myślę, naruszeniem piątego przykazania. Po drugie, w zakresie wolnej woli ludzi nie ma wyboru pomiędzy istnieniem a nieistnieniem rządu, ponieważ nie należy do wolnej woli posłuszeństwo lub nieposłuszeństwo wobec sądu natury, który jest sądem Boga, a sąd ten stwierdza, że społeczeństwa cierpią a ludzkość ginie, gdy nie wyznaczy się żadnego rządu (Rutherford 1843, 5).

Reasumując, do jego powołania dochodzi wskutek horyzontalnie rozumianego przymierza, gdzie równe sobie, umawiające się strony dokonują powołania państwa; jedna strona kontraktu staje się władcą, pozostałe jej poddanymi. Dochodzi przy tym do wzajemnego zobowiązania (mutual covenant), wedle którego król rządzi zgodnie z prawem, a ludzie są zobowiązani do posłuszeństwa władzy, a obie strony uprawnione są do wzajemnego przymuszenia do przestrzegania warunków umowy. Kontrakt ten nie może zostać w normalnych warunkach anulowany, chyba że na mocy zgodnej woli obu stron. Zatem król nie stoi ponad przymierzem i ponad prawem, które uczyniły go królem. Królowie, którzy są rozumnymi ojcami i przewodnikami swego ludu, którzy władają zgodnie z prawem, dbają o pokój wewnętrzny i bezpieczeństwo, wyprowadzają swą władzę z kontraktu i przymierza z ludem, stając się strażnikami wszystkich dobrych praw. Zatem z samej swej istoty władza polityczna podlegać musi prawu i nie może być tyrańska, a jeśli taką się staje, stoi za nią nie Bóg, lecz szatan. „Władza absolutna - pisze więc Rutherford - to zasadniczo władza, która obywa się bez prawa 
lub stoi ponad prawem, władza, by czynić zło, by niszczyć, zatem nie może ona pochodzić od Boga" (Rutherford 1843, 228). Władza, która pochodzi od Boga, z natury swej jest ograniczona, ponieważ, zdaniem Rutherforda, Stwórca nie daje władzy, by czynić zło. Wykonywanie jej musi być sprawiedliwe, a jej czyny moralne. Istnienie monarchii absolutnej sprzeczne jest więc z prawem natury: „Być królem i absolutnym władcą jest dla mnie sprzeczne. Król zasadniczo jest żywym prawem, ten zaś, kto ma władzę absolutną, jest stworzeniem zwanym tyranem, a nie legalnym królem" (Rutherford 1843, 111). Ludzie nie mają ponadto możliwości ,zrzec się takiej władzy na rzecz księcia” (Rutherford 1843, 46). Wolność jest bowiem częścią porządku natury i elementem przyrodzonej ludzkiej konstytucji.

Jest fałszem - czytamy w innym miejscu - że ludzie mogą za sprawą prawa natury złożyć całą wolność w ręce króla. 1. Nie mogą odstąpić tego, czego nie posiadają, Nemo potest dare quod non habet; bo ludzie nie mają w sobie absolutnej władzy, by zniszczyć siebie, bądź wykonywać tyrańskie czyny, o których mówi 1 Sam. VIII. 11-15, ponieważ ani Bóg, ani prawo natury nie dało im takiej władzy. 2. Ten, który czyni siebie niewolnikiem, czyli gorszym od wszystkich wolnych ludzi, jest zmuszony przez przemoc, przymus lub skrajną konieczność do tego nienaturalnego aktu alienacji od wolności, którą ma przez urodzenie od swego Stwórcy. Lecz ludzie nie czynią z siebie niewolników, gdy ustanawiają króla nad sobą, ponieważ Bóg, dając ludowi króla, najlepszego i najwybitniejszego naczelnika na ziemi, daje błogosławieństwo i szczególna łaskę (Rutherford 1843, 81-82).

Skoro więc przeciwstawienie się władzy sprawiedliwej jest występkiem przeciwko Bogu, to opór wobec tyranii nie niesie z sobą negatywnej moralnej oceny. „Nie ma żadnego powodu - pisze Rutherford - by zastrzeżenia wyrażone w przymierzu pomiędzy królem i ludem były czymś więcej, niż te zawarte w kontrakcie małżeńskim pomiędzy mężem a żoną. Obok dożywocia powinien zawrzeć klauzulę, że jeśli mąż będzie próbował zabić żonę lub żona męża, to w takim przypadku będzie legalne, by rozwiązać takie małżeństwo. Jak powiedział dr Feme: «Osobista obrona jest legalna, jeżeli napaść króla jest nagła, nielegalna lub niechybna». Lecz zastrzeżenie o możliwości obrony przed władzą nie musi być wyrażone w kontrakcie pomiędzy królem i ludem. Zasady prawa natury nie mogą zostać unieważnione w przymierzach prawa pozytywnego, ponieważ to one są ich podstawą" (Rutherford 1843, 118).

Król, jako król - czytamy zaś w innym miejscu - i na mocy swego królewskiego urzędu, jest ojcem królestwa, wychowawcą, obrońcą, tarczą, przywódcą, pasterzem, mężem, patronem, stróżem, pasterzem ludu, nad którym panuje, a zatem urząd ten zawiera przede wszystkim akty ojcowskiego uczucia, troski, miłości i życzliwości dla tych, nad którymi jest ustanowiony, zatem jak ci, którzy są obleczeni w te wszystkie relacje miłości nie mogą wykonywać swych działań przeciwko ludziom wbrew ich woli i za pomocą przemocy. Czy można być ojcem, przewodnikiem i patronem wbrew naszej woli i wyłącznie dzięki mocy krwawego miecza? (Rutherford 1843, 47)

Tym zatem, co czyni króla królem i rodzi skuteczne polityczne zobowiązanie, jest podleganie prawu - „król, jako król, będąc lex animata, oddychającym 
i żywym prawem, królem, jako król musi być podporządkowany prawu, które uczyniło go królem” (Rutherford 1843, 98). Dlatego dla Rutherforda: „Prawo posiada konstytucyjną supremację nad królem. Ponieważ król nie jest królem z natury, jak zostało udowodnione, dlatego musi być królem za sprawą rozważnej konstytucji i prawa i dlatego prawo stoi ponad królem" (Rutherford 1843, 126).

Jeśli idzie o konkretne rozwiązania ustrojowe, w ramach których ma mieć miejsce supremacja prawa nad królem, to Rutherford odwołuje się do tradycji ustrojowej i klimatu intelektualnego ówczesnej Brytanii. Biorąc je pod uwagę, jest więc przekonany, że:

Ograniczona i mieszana monarchia, taka jak w Szkocji i Anglii, wydaje mi się najlepszym ustrojem. (...) Ustrój ten ma chwałę, porządek, jedność od monarchy; od rządu wielu najmądrzejszych ma pewność rady, stabilność, siłę; z wpływu ludu czerpie wolność, przywileje, szybkość posłuszeństwa (Rutherford 1843, 192).

W ustroju takim to Parlament, zdaniem Rutherforda, zajmuje centralne miejsce w systemie instytucjonalnym państwa, będąc wyrazicielem woli i strażnikiem praw ludu, będącego źródłem władzy politycznej monarchy. Dlatego przekonuje, że:

Parlament jest zazwyczaj równorzędny królowi we władzy tworzenia prawa; ale równorzędność króla pochodzi od parlamentu, orginaliter et fontaliter, jako jej źródła; 2 . W zwykłym biegu spraw mamy do czynienia z równorzędnością, lecz jeśli król zamienia się w tyrana, wtedy stany używają swej pierwotnej władzy (Rutherford 1843, 115).

Władza królewska sprawowana jest z woli Parlamentu dokonującego wyboru monarchy bądź akceptującego jego władzę, jest władzą pierwotną wobec urzędu królewskiego. „Sądzę - pisze więc Rutherford - że byłoby dziwne i pozbawione sensu, by władza dana królowi przez parlament lub stany wolnego królestwa (...) mogła tworzyć, regulować, ograniczać, pozbawiać, zaprawdę, i anulować władzę, która ją stworzyła" (Rutherford 1843, 185). Oddzielony od Parlamentu król nie może zdziałać niczego, dlatego władza króla i Parlamentu są skoordynowanymi częściami najwyższej władzy królestwa podlegającymi Bogu: „Parlament daje najwyższą władzę królowi, dlatego, by zapobiec tyranii, musi mieć równorzędną z królem władzę w najważniejszych sprawach" (Rutherford 1843, 114). Podobnie Rutherford określa pozycję sędziów wobec króla, starając się uczynić ich maksymalnie od niego niezależnymi. Wiąże się to oczywiście z absolutnym prymatem prawa nad arbitralną wolą władcy. Sędzia jest w istocie zastępcą króla i sądzi w jego imieniu, równocześnie będąc sędzią, poddany jest tak samo władzy i rozkazom Boga jak król, który go mianował. Król, czyniąc to, przekazuje sędziemu swe prawo sądzenia otrzymane od Boga, przez co sędzia nie podlega odtąd jego woli w akcie orzekania, a „zadowolenie króla nie może być regułą sumienia niższego sędziego, ponieważ dostaje on natychmiastowe upoważnienie od Boga" (Rutherford 1843, 137). Sędziowie podlegają zatem prawu bożemu i naturalnemu, które jest jedynym probierzem legalności prawa stanowionego, a nie kaprysom króla. Sędziowie bowiem, jak wszyscy funkcjonariusze państwowi, wyprowadzają ostatecznie 
swą władzę z woli Boga, miecz w akcie tworzenia państwa przekazany został tak królowi, jak i podwładnym mu urzędnikom, stąd ,święty majestat jest we wszystkich niższych sędziach, w każdym zwierzchniku, dlatego zasługują oni na cześć, strach i szacunek” (Rutherford 1843, 175). Stąd nie tylko król, lecz ,wszyscy posiadający władzę są zobowiązani, by dbać o to, by poddani prowadzili spokojne i pokojowe życie w pobożności i uczciwości" (Rutherford 1843, 92). Zobligowani są więc do ochrony i zachowania prawdziwej religii oraz obrony poddanych przed przemocą i gwałtem niezależnie od działań monarchy. Stąd natura i źródło władzy króla i wszystkich urzędników jest identyczne, a ,wyrok wydany przez niższych sędziów - dowodzi więc Rutherford - jest wyrokiem Pana, dlatego śmiertelny król nie może przeszkodzić w jego wydaniu" (Rutherford 1843, 91). Można zatem stwierdzić, że urzędnicy i sędziowie są odpowiedzialni przede wszystkim przed Bogiem i to Jego wolę w pierwszym rzędzie muszą realizować, nie mniej niż król reprezentują na ziemi jego władzę, będąc wikariuszami i zastępcami Stwórcy.

\section{PRAWO KRÓLESTWA CZY PRAWO BOŻE?}

Widać do tej pory, że argumentacja Rutherforda wpisuje się w długą, angielską tradycję monarchii prawa i takie wrażenie odnieść mógł angielski czytelnik Lex, Rex, odnoszący jego treść do postulatów parlamentarnych prawników, formułowanych od czasów Jakuba I. Gdy bowiem Rutherford pisze o prawie, to naturalnym punktem odniesienia była przede wszystkim konstrukcja ancient constitution Edwarda Coke’a. Zgodnie ze sformułowaną przez niego koncepcją, nie istniało coś takiego, jak historia angielskiego prawa, pozostało ono bowiem niezmienione od najdawniejszych czasów, sięgających jeszcze okresu sprzed normańskiego najazdu. Jego treść była więc niezależna od politycznych wstrząsów, targających przez stulecia Wyspami. Było też prawem doskonałym, efektem odwiecznego zwyczaju, swoistego mistycznego procesu, udowadniającym wartość poprzez skuteczne funkcjonowanie sięgające czasów niepamiętnych. Starożytna konstytucja nie była przy tym dziełem żadnego mitycznego prawodawcy, a jej początki niknęły w pomroce dziejów (Pocock 1957, 36). Nie można było więc odnaleźć ich ani w ludzkiej pamięci, ani w dokumentach historycznych, a jedynie w kolejnych jego potwierdzeniach przez monarchów i sądy. Podstawą argumentacji Coke’a była Wielka Karta, traktowana przez niego jako ucieleśnienie ponadczasowych maksym common law, święty tekst, nieodwołalny, fundamentalny statut, prawo praw, potwierdzała bowiem odwieczne prawo Anglii (Coke 1817, 14). Skoro tak, to oczywista była wyższość i pierwszeństwo tego starożytnego prawa przed prawem stanowionym przez jakiegokolwiek prawodawcę, które może być jedynie potwierdzeniem odwiecznego zwyczaju, podobnie jak wyroki sądów oznajmiające jedynie i potwierdzające starożytne prawo królestwa. Common law stało więc ponad jakimkolwiek politycznym autorytetem i nie mogło być przez niego 
zmienione. Coke splótł więc jego niezmienność z niezmiennością i odwiecznością instytucji życia zbiorowego, ze starożytnym charakterem angielskiej konstytucji oraz swobód Anglików, którymi mieli cieszyć się od czasów najdawniejszych. Wynikało stąd podporządkowanie władcy autorytetowi prawa i zasadom odwiecznego ustroju (Coke 1826 - Calvin's Case 4a, 6), które nie powstały w efekcie ludzkiej działalności, lecz wyrażają rozumność prawa natury oraz boskiego porządku. Opierający się na takim założeniu program polityczny polegał więc na restytucji starożytnej konstytucji zagrożonej przez królewskie prawodawstwo i renesansową koncepcję suwerenności (Brooks 2008, 54). Zamiast wspierać więc króla, zgodnie z rzymskimi tradycjami, prawo powinno stać ponad królem, być bezstronnym arbitrem w sporach toczonych w królestwie. Starożytna konstytucja stałą się więc dla Coke'a i obozu parlamentarnego punktem odniesienia dla wizji ustroju forsowanego przez Stuartów oraz konkretnych działań monarszych.

Wydaje się jednak, że nie dla Rutherforda, w ojczyźnie którego dążenie do ograniczenia władzy monarszej miało całkowicie inne podłoże. Choć więc na pierwszy rzut oka posługuje się terminologią miłą i znaną angielskiemu uchu sprzeciwiającemu się tyrańskim zapędom królów, to rozumie przez nią coś zgoła innego. Kluczem do wyjaśnienia tej dychotomii jest bliższa analiza jego kontraktualnej genezy władzy politycznej. Nie można bowiem umowy, o której pisze Rutherford, redukować jedynie do jej horyzontalnego wymiaru pomiędzy ludem i królem. Pamiętać należy, że wybór ludu kierowany jest przez Boga, zatem, co bardzo dla Rutherforda istotne: „nie możemy mówić tutaj o dwóch aktach, jednym Boga, drugim ludzi, ale o jednym i tym samym działaniu; Bóg poprzez wolny wybór i głos ludzi czyni takiego człowieka Królem, pomijając tysiące innych" (Rutherford 1843, 7). W ten sposób władza pochodzi bezpośrednio od Boga i bezpośrednio od ludzi, zatem „Bóg tylko przez działanie ludzi jako jego narzędzia, może uczynić królem" (Rutherford 1843, 202). Kontraktowy, wertykalny (Coffey 1997, 165) charakter mają wiec także relacje pomiędzy królem i Bogiem. Otrzymując władzę rządcy, przyjmuje na siebie przede wszystkim zobowiązanie wobec Stwórcy do przestrzegania prawa Bożego. Zobowiązanie to jest szczególnie silne, jeśli chodzi o władców Szkocji i Anglii. Rutherford był bowiem przekonany o przymierzu, które wzorem starożytnego Izraela łączy Szkocję z Bogiem. Jej historia podobna jest do dziejów starożytnego Izraela i tak samo, jak Izrael, Szkocja stała przed wyborem: posłuszeństwo Bogu przynieść miało błogosławieństwa, nieposłuszeństwo zaś przekleństwo i katastrofę. Katastrofę, której można było uniknąć przez całkowite zawierzenie Bogu i stanie się początkiem powszechnego odkupienia poprzez odrzucenie rzymskiego Antychrysta i ustanowienie rządów Boga nad wszystkimi narodami ziemi. „Dwa parlamenty Szkocji i Anglii - pisze Rutherford - odnowiły przymierze nie przeciw królowi, ale by przywrócić religię do starożytnej czystości, mając to prawo wyraźnie od króla Jakuba i Karola oraz wiele aktów parlamentu, by utrzymać religię czystą" (Rutherford 1843, 136). 
„Te dwa królestwa mają przed sobą cel, jakim jest przymierze, by być ludem Bożym" - pisze gdzie indziej.

Niech błogosławi im Pan - kontynuuje - który pośredniczy dla zapobieżenia ich zerwaniu i działa dla trwania tego braterskiego przymierza. Chrystus jest jednoczącym Zbawcą, jedynym Bogiem, jedną wiarą, jednym Panem Jezusem Chrystusem, powinna być więc jedna religia, dlatego prosimy Boga pokoju, by połączył złotymi łańcuchami te dwa narody razem in uno tertio, by były zgrupowane i połączone w jednym Panu Jezusie (Rutherford 1646a, strony nienumerowane).

Konsekwencją tego „Narodowego Przymierza jest obowiązek wykorzenienia wszystkich fałszywych religii, które są przeciwne prawdziwej doktrynie" (Rutherford 1649, 270). Anglia zaś winna dokonać tego samego - odnowić przymierze zerwane przez odstępstwo na rzecz rzymskiego bałwochwalstwa (Rutherford 1843, 182) - opierając swą konstytucję na przymierzu i wzorując na prawie naturalnym (Coffey 1997, 144). Herezja ,jest bowiem grzechem przeciwko pierwszemu przykazaniu i tej nieskazitelnej zasadzie natury wyrytej w sercu człowieka, «że jest tylko jeden prawdziwy Bóg i tylko jemu trzeba służyć»»" (Rutherford 1649, 187). Dlatego jako chrześcijanin nie może ograniczać jedynie celów człowieka i całej wspólnoty do wymiaru doczesnego.

Każda władza - pisze Rutherford - by rozkazywać, grozić, obiecywać, karać, więzić, nagradzać jest władzą daną przez Boga rodzicom, głowom rodzin, nauczycielom, opiekunom, Królom i Książętom, jest darem Boga i musi być wykorzystywany dla dobra dusz, by przestrzegać przykazań pierwszej Tablicy przez każdego, wedle jego pozycji (Rutherford 1649, 145).

Stąd, argumentuje dalej: „Książę, Parlament, podobnie Urzędnicy, zgodnie ze swą pozycją jako ojców wspólnego dobra, muszą się o nie troszczyć" (Rutherford 1649). Dlatego celem najważniejszym i ostatecznym musi pozostać ciągle zbawienie człowieka, a państwo personifikowane osobą władcy ma w tym pomóc i na nim ciąży ten szczególny obowiązek. Celem rządu jest stosowanie i realizacja prawa Bożego, odkrytego przez doświadczenie i danego wprost przez słowa Pisma Świętego. Jest zatem formalnie ucieleśnieniem prawa Boga. Dlatego królowie

są Boskimi narzędziami i Sługami w: 1. Przedkładaniu i objaśnianiu praw Bożych; 2. W egzekwowaniu ich i obronie przed przemocą ludzi; 3 . W tworzeniu praw politycznych, dla rządu politycznego, które wiążą sumienie, dopóki zgodne są z Prawem Bożym (Rutherford 1646b, 208).

W jego narracji rolę starożytnej konstytucji pełni więc zawarty w Biblii, przede wszystkim zaś w Starym Testamencie, przekaz Boga. Konsekwencją jest ambicja powołania opresyjnego państwa, w którym starożytne wolności i common law nie mają priorytetu, lecz muszą ustąpić miejsca prawu biblijnemu. Celem polityki jest bowiem przygotowanie miejsca nowemu królestwu, poprawa świata, gdzie człowiek jest pobożny i sprawiedliwy. Z tego powodu właśnie władca musi „wywrzeć zemstę za bluźnierstwo, bałwochwalstwo, jawną niewiarę" (Rutherford $1644,395)$. 


\section{REKAPITULACJA}

O ile więc celem koncepcji monarchii prawa w wieku XVII w Anglii było, zwłaszcza w kręgach parlamentarnych, przywrócenie właściwych, uświęconych tradycją prawną i polityczną, relacji instytucjonalnych, o tyle Rutherford, posługując się identyczną niemal terminologią, pragnie dokonać czegoś innego. Jego archetyp zaklęty jest nie w starych precedensach i praktyce konstytucyjnej, lecz w prawie Bożym, zrównanym przez niego z prawem naturalnym. Prawo natury zaszczepione zostało w człowieku, by mógł się nim kierować i odróżniać dobro od zła. Pochodzi od samego Boga, który zapisał je swą dłonią w naszych sercach i powiązał z ludzką naturą tak, by człowiek poznał, co to sprawiedliwość i dobro. Choć zgodnie z klasyczną kalwińską tradycją (Calvin i 1960, 206) Bóg jest „powszechnym i całkowitym Panem i Właścicielem nieba, ziemi i wszystkich, którzy w nich są" (Rutherford 1655, 38), to w naturalnych ludzkich skłonnościach odbijają się Boskie zamiary. By jednak móc argumentować w prawdziwie chrześcijańskim stylu, Rutherford musi znaleźć w swej teorii prawa miejsce na łaskę. Zatem reguły te mogą być jednak rozpoznane, na skutek Upadku Adama, tylko za sprawą działalności Ducha Świętego, dlatego „natura nie jest wystarczającą wskazówką tego, co czynić, by osiągnąć życie wieczne" (Rutherford 1646b, 76). Bóg zaszczepił poprzez prawo natury w sercu człowieka pewne naturalne skłonności, które przyjmują formę nakazu i każą mu działać w określony sposób. Lecz człowiek naturalny, który nie zna prawdziwego Boga, jest nieświadomy podstaw swych zobowiązań. Dlatego jego naturalne dobre działania są niedoskonałe, ponieważ motywowane są przez cielesną wolę i żądzę, a nie ponieważ rozkazał tak Stwórca w prawie natury (Rutherford $1646 b, 79$ ) . Do porządku natury należy z samej istoty bycie częścią Bożego dzieła, do porządku łaski zaś jedynie na mocy wybraństwa. Skoro więc sama natura nie wystarcza jako źródło norm moralnych, potrzebne jest Słowo Boże, by zrozumieć zamiar Stwórcy wobec rodzaju ludzkiego. Do pełnego rozumienia natury konieczny jest więc Boski autorytet Pisma Świętego. Słowo i Duch muszą działać więc razem, Słowo jest rozumne, lecz wymaga Ducha, a Duch działa tylko przez Słowo. Monarchia prawa nie polega więc na podleganiu władzy państwowej starożytnemu prawu, które wciela we właściwy dla danej wspólnoty sposób zamysł Stwórcy, lecz Jego bezpośrednim nakazom wyrażonym w Biblii. Odrzuca zatem to, co charakterystyczne dla angielskiej tradycji i co najlepiej wyraził przed nim Hooker, dla którego większość ludzi nie jest w stanie poprzez indywidualną refleksję poznać nakazów prawa naturalnego, a przez to wskazać treści naturalnych zobowiązań. Dlatego dla większości źródłem zobowiązania politycznego jest po prostu prawo pozytywne jako takie, bez odnoszenia do treści prawa naturalnego, ostatecznie więc przestrzeganie prawa wypływa z nawyku wytworzonego przez taką postawę. Dlatego historia i tradycja mają dla Hookera fundamentalne znaczenie, stając się podstawą obrony 
średniowiecznej tradycji angielskiej, z której wywodzą się wszystkie urządzenia społeczne (Preece 1980, 16). Rozum indywidualny musi bowiem czasem ustąpić przed rozumem zbiorowym, ukształtowanym przez mądrość i doświadczenie minionych generacji (Wolin 1953, 36).

Świat - pisze więc Hooker - nie zniesie tego, gdy usłyszy, że jesteśmy mądrzejsi, niż ci, którzy byli wcześniej. W tym właśnie tkwi przyczyna, dla której powinniśmy być opieszali i niechętni zmianie, bez bardzo pilnej konieczności, starożytnych Nakazów, Obrzędów i długo istniejących Zwyczajów naszych czcigodnych poprzedników (Hooker 1820, 27).

Dla Rutherforda tymczasem stare wolności Anglików nie są efektem ewolucyjnego rozwoju, lecz polegają ostatecznie na prawie do wyznawania jedynej prawdziwej religii, a więc ,tolerancji”, rozumianej w prezbiteriański, a zatem ostatecznie opresyjny, sposób. Rutherford jest bowiem dzieckiem kalwińskiej reformacji podkreślającej absolutną supremację Prawa Bożego, a zawarte w Słowie nakazy traktującej jako jedyny probierz dobra i zła oraz przewodnik po teorii politycznej, stare instytucje służyć mają zaś jedynie jego realizacji.

W tej wewnętrznej skrytce - pisze Rutherford - naturalnym zwyczaju moralnych zasad przetrwał rejestr wspólnych pojęć zostawionych nam przez naturę, starożytne zapiski i kroniki z czasów Adama i dwa tomy Prawa Natury. Pierwsza Tablica mówi, że jest jeden Bóg, który jest stworzycielem i władcą wszystkich rzeczy, że jest jeden Bóg, nieskończenie dobry, sprawiedliwie odpłacający za zło i dobro. Druga dotycząca ludzkich działań mówi, by kochać swych rodziców, słuchać zwierzchników, nie krzywdzić innych ludzi (Rutherford 1649, 7).

Jego absolutny prymat powodował, że nikt, ani król, ani wspólnota, nie mogły podążać inną ścieżką, niż ta wytyczona przez Biblię, a w istocie jej prezbiteriańskich interpretatorów. Odstępcy zaś, na mocy prawa Bożego, są zwykłymi złoczyńcami, na równi ze złodziejami i mordercami i na równi z nimi spotkać ich musi zasłużona kara.

Ponieważ tylko Bóg - pisze Rutherford - nie Mojżesz czy inny podległy mu prawodawca, określa, że na śmierć zasługuje cudzołożnik. I tylko On określa karę za umyślne morderstwo, uderzenie ojca lub matki, kradzież, czarnoksięstwo, sodomię, oddawanie czci obcemu bogu. Na tej samej zasadzie Bóg tylko, a nie jakiś śmiertelnik, musi określić karę należną dla tych, którzy zwodzą dusze dla wiecznego potępienia (Rutherford 1649, 309).

Tolerowanie takich występków, jest nie tylko sprzeczne z zewnętrznym spokojem wspólnoty i naturalnym szczęściem społeczeństw, lecz również sprzeczne z nadnaturalnym szczęściem Kościoła jako wspólnotą wiernych w drodze do szczęścia wiecznego" (Rutherford 1649). 


\section{BIBLIOGRAFIA}

Brooks, Christopher W. 2008. "The Place of Magna Carta and The Ancient Constitution in Sixteenth-Century English Legal Thought". W: The Roots of Liberty: Magna Carta, Ancient Constitution, and the Anglo-American Tradition of Rule of Law. Pod redakcją Sandoz Elis. 75-114. Indianapolis: Liberty Found.

Calvin, John. 1960. Institutes of the Christian Religion. Tłumaczenie Ford L. Battles. Louisville: Westminster John Knox Press.

Campbell, William, "Lex, Rex and its author". Records of the Scottish Church History Society 7: 204-228.

Coffey, John. 1997. Politics, Religion and the British Revolutions. The Mind of Samuel Rutherford. Cambridge: Cambridge University Press.

Coke, Edward. 1817. The Second Part of Institutes of the Laws of England. London: W. Clarke and Sons.

Coke, Edward. 1826. The Reports of Sir Edward Coke. Vol. IV. London: Joseph Butterworth and Son.

Elazar, Daniel Judah. 1995. Covenant and Polity in Biblical Israel. Biblical Foundations and Jewish Expressions. The Covenant Tradition in Politics. Vol. I. New Brunswick, New Jersey, London: Transaction Publishers.

Elazar, Daniel Judah. 1996. Covenant and Commonwealth. From Christian Separation through the Protestant Reformation. The Covenant Tradition in Politics. Vol. II. New Brunswick: Transaction Publishers.

Gough, John Wiedhofft. 1975. The Social Contract. A Critical Study of its Development. Oxford: Clarendon Press.

Hooker, Richard. 1820. "Of the Laws of Ecclesiastical Polity". W: The Works of Richard Hooker. Oxford: Clarendon Press.

Miller, Perry. 1956. Errand into the Wilderness. Cambridge: Harvard University Press.

Pocock, John Greville Agard. 1957. The Ancient Constitution and the Feudal Law. A Study of English Historical Thought in the Seventeenth Century. Cambridge, New York: Cambridge University Press.

Preece, Rod. 1980. "The Anglo-Saxon Conservative Tradition". Canadian Journal of Political Science 13 (1): 3-32.

Rutherford, Samuel. 1644. The due right of presbyteries, or, A peaceable plea for the government of the Church of Scotland. London: E. Griffin.

Rutherford, Samuel. 1646a. "To The Right Honorable and Noble Lord, The Earl of Lovden, Chancellor of Scotland; and Chancellor of the University of St. Andrews, Grace, Mercy and Peace". W: Samuel Rutherford. The divine right of church-government and excommunication: or a peacable dispute for the perfection of the holy scripture in point of ceremonies and church government. London: John Field.

Rutherford, Samuel. 1646b. The divine right of church-government and excommunication: or a peacable dispute for the perfection of the holy scripture in point of ceremonies and church government. London: John Field.

Rutherford, Samuel. 1649. A free disputation against pretended liberty of conscience tending to resolve doubts moved by Mr. John Goodwin, John Baptist, Dr. Jer. Taylor, the Belgick Arminians, Socinians, and other authors contending for lawlesse liberty, or licentious toleration of sects and heresies. London: Andrew Crook.

Rutherford, Samuel. 1655. The covenant of life opened, or, A treatise of the covenant of grace. Edinburgh: Andro Anderson. 
Rutherford, Samuel. 1843. Lex, Rex, or The Law and the Prince; A dispute for The Just Prerogative of King and People: containing The reasons and causes of the most necessary defensive wars of the Kingdom of Scotland, and of their Expedition for the aid and help of their dear brethren of England; in which their innocency is asserted, and a full answer is given to a seditious pamphlet, entitled, Sacro-Sancta Regnum Majestatis. Edinburgh: Robert Ogle and Oliver \& Boyd.

Sanderson, John. 1989. 'But the People's Creatures'. The philosophical basis of the English Civil War. Manchester, New York: Manchester University Press.

Wolin, Sheldon. 1953. "Richard Hooker and English Conservatism". The Western Political Quarterly 6 (1): 28-47.

\title{
Tomasz Tulejski
}

\section{SAMUEL RUTHERFORD - THE MONARCHY OF LAW OR THE MONARCHY OF SAINTS?}

\begin{abstract}
Samuel Rutherford - Scottish Presbyterian priest and political thinker who lived in the times of English civil war - is commonly considered as one of the theorists of the monarchy of law concept, the mixed constitution and the right of revolution. All these ideas are fundamental for modern English constitutionalism which is in opposition to the idea of monarchical absolutism which is based on the concept of the social contract. For this reason, he was among the authorities quoted by the Founding Fathers during their opposition against the arbitrary powers of the Metropole. Meanwhile, the global analysis of his achievements put in doubts many circulating opinions regarding the author of Lex, Rex. In this article, an author proves that the hermeneutic analysis of Rutherford's political theology suggests that Rutherford was not the theorist of the monarchy of law in its common meaning, but rather theonomic vision of the state.
\end{abstract}

Keywords: Rutherford; monarchy of law; English Civil War. 